\title{
New localities of rare amphibians (Amphibia) and reptiles (Reptilia) in the Świętokrzyski National Park
}

\author{
Dariusz WOJDAN \\ *Świętokrzyska Academy, Świętokrzyska 15, 25-406 Kielce, Poland; e-mail: dwojdan@pu.kielce.pl
}

\begin{abstract}
In the Świętokrzyski National Park 14 species of amphibians and 6 species of reptiles were found in the years 2002-2005. Special attention was paid to the occurrence of rare and vulnerable species: Pelobates fuscus and Bufo calamita (amphibians), Coronella austriaca (reptile) and to the identification of breeding localities of amphibians. As a result of the research 25 water bodies with regularly breeding amphibians were found. Only four water bodies held rare species of amphibians.
\end{abstract}

Key words: amphibians, reptiles, distribution, Świętokrzyski National Park, Poland

\section{INTRODUCTION}

The occurrence of amphibians and reptiles in the Świętokrzyski National Park has been the subject of scarce research so far (Ćmak \& Zbożeń 1985, Kowalewski 1985). Unfortunately, the data from the mentioned publications were collated over 20 years ago and are not up-to-date any more.

Breeding sites of amphibians, including rare species (Kowalewski 1985), have not been recorded. Recent publications cover larger areas (Ichniowska-Korpula 1994) or only Triturus species (Wojdan 1997). The presented publication is the first one that describes the occurrence of amphibians and reptiles within the new borders of the Świętokrzyski National Park. Special attention was paid to identify the occurrence and distribution of rare species (Kowalewski 1985).

\section{STUDY AREA, MATERIALS AND METHODS}

The research was carried out in the years 2002-2005 in the area of the Świętokrzyski National Park (7 626.45 ha) and in its buffer zone (20 786.07 ha) - (Fig. 1). This area was divided into 260 squares of the size $1 \mathrm{~km} \times 1 \mathrm{~km}$. The division of the Park into squares and the location of the research sites was done with a GPS system that is combined with a similar one in the Park.

Individual squares were checked at least once a year. Special attention was paid to water bodies as potential breeding localities of amphibians. These water bodies were checked more often, especially in the period from March to August. The total catch method was applied.

All amphibians were released to the same water bodies after being identified (species and sex) and measured. Additionally, the occurrence of anurans (Anura) was estimated on the basis of breeding calls of males. However, this method could not be used to estimate the number of animals, as it is not very precise. The observations in terrestrial localities were treated as a supplementary method. 


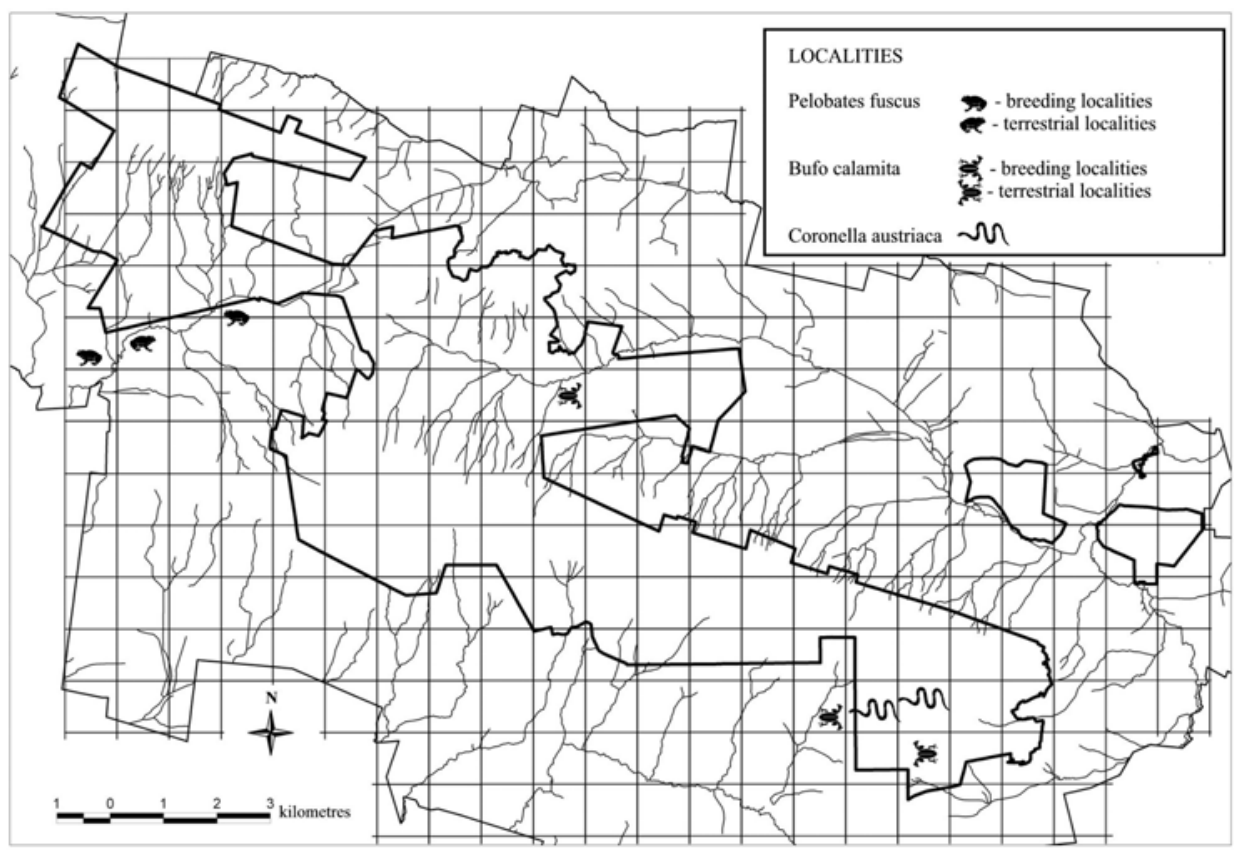

Fig. 1. Localities of rare amphibians (Amphibia) and reptiles (Reptilia) in the Świętokrzyski National Park; the border of the National Park is marked by a solid line.

\section{RESULTS}

In the area of the Świętokrzyski National Park and its buffer zone 14 species of amphibians and 6 species of reptiles were found (Table 1). The common amphibian species were: Triturus cristatus, T. vulgaris, T. alpestris, Bombina bombina, Bufo bufo, B. viridis, Hyla arborea, Rana lessonae, $R$. esculenta, $R$. ridibunda, $R$. temporaria and $R$. arvalis. All the listed species were found in more than three breeding localities (in water bodies). In total, amphibians mated in 25 water bodies in the areas of the Świętokrzyski National Park and its buffer zone. Some species: Triturus cristatus, T. vulgaris, T. alpestris, Pelobates fuscus, Bufo bufo, B. viridis, B. calamita, Hyla arborea, Rana temporaria, $R$. arvalis were also observed in terrestrial habitats. 3 species: $B$. bombina, $R$. lessonae and $R$. ridibunda were widespread but not numerous.

Rare species of amphibians in the Świętokrzyski National Park were Pelobates fuscus and Bufo calamita. Reptiles were represented in this group only by Coronella austriaca (Fig. 1, Table 2).

The common reptiles were: Lacerta agilis, L. vivipara, Anguis fragilis, Natrix natrix and Vipera berus (Table 1). Among them the most common was L. vivipara.

Pelobates fuscus was present only in the western part of the Park (Wilków and Ciekoty). The species was found in two water bodies. Both mature individuals and tadpoles were observed. Additionally, P. fuscus was observed at nights in terrestrial habitats in a distance of less than one kilometre from one of the water bodies (Fig. 1). The habitat of this species covered arable fields and their vicinities. It was located in loose and sandy soils.

Bufo calamita was found in a few localities, although it was also rare, like the previously described species. Mature individuals were found in water bodies in the central (Czarna Woda) 
and eastern part of the Park (Huta Szklana). In the outflows of the Czarna Woda river tadpoles of this species were found, too. In terrestrial habitats Bufo calamita was found in forest communities Dentario glandulosae-Fagetum (Klika), south from the Święty Krzyż mountain (Fig. 1).

Table 1. Checklist of amphibian and reptile species found in the Świętokrzyski National Park in the years 2002-2005

\begin{tabular}{|c|c|c|c|}
\hline No. & Species & $\begin{array}{l}\text { Total number of localities found } \\
\text { during the whole research period }\end{array}$ & $\begin{array}{l}\text { Maximal number of individuals } \\
\text { caught during one year }\end{array}$ \\
\hline 1 & $\begin{array}{c}\text { Amphibia } \\
\text { Triturus cristatus (Laur.) }\end{array}$ & 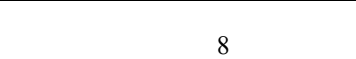 & 79 \\
\hline 2 & Triturus vulgaris (L.) & 21 & 370 \\
\hline 3 & Triturus alpestris (Laur.) & 26 & 630 \\
\hline 4 & Bombina bombina (L.) & 6 & 11 \\
\hline 5 & Pelobates fuscus (Laur.) & 3 & 5 \\
\hline 6 & Bufo bufo (L.) & 16 & 125 \\
\hline 7 & Bufo viridis Laur. & 6 & 30 \\
\hline 8 & Bufo calamita Laur. & 2 & 4 \\
\hline 9 & Hyla arborea (L.) & 9 & 18 \\
\hline 10 & Rana lessonae Cam. & 7 & 9 \\
\hline 11 & Rana esculenta $\mathrm{L}$. & 13 & 92 \\
\hline 12 & Rana ridibunda Pall. & 5 & 7 \\
\hline 13 & Rana temporaria $\mathrm{L}$. & 25 & 891 \\
\hline 14 & $\begin{array}{r}\text { Rana arvalis Nilss. } \\
\text { Reptilia }\end{array}$ & 11 & 112 \\
\hline 15 & Lacerta agilis $\mathrm{L}$. & 22 & 63 \\
\hline 16 & Lacerta vivipara (Jacquin) & 37 & 175 \\
\hline 17 & Anguis fragilis $\mathrm{L}$. & 20 & 7 \\
\hline 18 & Natrix natrix (L .) & 17 & 11 \\
\hline 19 & Coronella austriaca Laur. & 2 & 1 \\
\hline 20 & Vipera berus (L.) & 11 & 4 \\
\hline
\end{tabular}

Coronella austriaca was found only in two closely located sites (within a distance of 800 m). Both sites are located south from the Święty Krzyż mountain, in partially overgrown rocky outcrops (stony fields on slopes) and neighbouring plant communities Abietetum polonicum (Dziub.) This species was observed several times but it was impossible to investigate its biology. Only mature individuals were observed. However, breeding of $C$. austriaca was not confirmed in this area.

Table 2. Number of localities of rare amphibians (Amphibia) and reptiles (Reptilia) in the Świętokrzyski National Park in the years 2002-2005.

\begin{tabular}{|c|l|c|c|c|}
\hline No. & Species & $\begin{array}{c}\text { Number of terrestrial } \\
\text { localities }\end{array}$ & $\begin{array}{c}\text { Number of breeding } \\
\text { localities of amphibians }\end{array}$ & $\begin{array}{c}\text { Number of observed } \\
\text { breeding individuals in 2004 }\end{array}$ \\
\hline 1 & Pelobates fuscus & 1 & 2 & 5 \\
\hline 2 & Bufo calamita & 1 & 2 & 4 \\
\hline 3 & Coronella austriaca & 2 & - & - \\
\hline
\end{tabular}

\section{DISCUSSION}

The characterisation of herpetofauna in the Świętokrzyski National Park revealed significant changes in comparison to the research carried out 20 years earlier (Ćmak and Zbożeń 1985, Kowalewski 1985, Ichniowska-Korpula 1994). Głowaciński (2001) lists among others Triturus cristatus and Coronella austraca as endangered species in Poland but he fails to mention Pelobates fuscus and Bufo calamita on this list. In the Świętokrzyski National Park the Triturus cristatus species is not rare, which had already been stated by Kowalewski (1985). 
This author had placed Bufo viridis, Bufo calamita, Lacerta agilis, Natrix natrix and Coronella austraca among rare species in this area and had not confirmed Pelobates fuscus and Rana lessonae, although they had been listed by Ćmak \& Zbożeń (1985) as well as IchniowskaKorpula (1994). Nevertheless, these authors had been conducting their research before the expansion of the Park borders and therefore it became crucial to revise and reconfirm the list of rare species of the Park's herpetofauna.

In general, endangered species in the area of the Świętokrzyski National Park are those which occur in unique environments and in small numbers. The list includes two amphibians Pelobates fuscus and Bufo calamita, and one reptile - Coronella austriaca. These are the most threatened species of the local herpetofauna.

Pelobates fuscus has been considered a rare species in the area of Poland. Rare species on the scale of Europe (Arnold \& Burton 1978) or Poland (Juszczyk 1987, Głowaciński 2001, 2002, Głowaciński \& Rafiński 2003) are not always rare in much smaller areas (e.g. in national parks) and vice versa. Contrary to the research of Kowalewski (1985) and Ichniowska-Korpula (1994) P. fuscus was found in the area of the Park and especially in its buffer zone. This species had been also found earlier by Ćmak and Zbożeń (1985). Scarce observations of this species can be explained by its shyness and by the fact that presently it can be found only in areas recently included into the Park. From among the mentioned authors Ichniowska-Korpula (1994) was the only one who carried out research in this area but she did not observe P. fuscus. This species can be regarded as potentially endangered in the Park but not critically endangered, yet.

Bufo calamita is a very rare species in Europe but quite widespread in Poland. The range of this species probably decreased in the Park because it was not found in the western part of the Park, where it had been observed by Kowalewski (1985). At the same time the species had been found by Ćmak and Zbożeń (1985) but they had not reported on any localities. $B$. calamita had been also observed by Ichniowska-Korpula (1994) in the Trzcianka locality very close to the locality reported by the author of this publication. It can be assumed that threats of extinction of this species significantly increased in the Świętokrzyski National Park.

Coronella austriaca is the most endangered species of the herpetofauna in the Park. It had been described by Ćmak and Zbożeń (1985) with no information on localities and by Kowalewski (1985). According to the latter author Coronella austriaca had been found in the area of the Łysica and Święty Krzyż mountains. Recently, the species has been found only in the locality to the south from the Święty Krzyż mountain. The previously described localities near Łysica and Święty Krzyż probably do not exist anymore. What is worse, even in the areas of its occurrence the snake is extremely rare, nearly extinct.

\section{REFERENCES}

ARnold E. N. \& Burton J. A. 1978. Reptiles and Amphibians of Britain and Europe. Collins, London, 272 pp.

ĆMAK J. \& ZBOŻEŃ J. 1985. Fauna płazów (Amphibia) i gadów (Reptilia) Świętokrzyskiego Parku Narodowego oraz warunki jej ochrony. Rocznik Świętokrzyski 12: 183-207.

GŁowACiŃSKi Z. (ed.). 2001. Polish Red Data Book of Animals. Vertebrates. Państwowe Wydawnictwo Rolnicze i Leśne, Warszawa, $452 \mathrm{pp}$.

GŁowACIŃSKi Z. 2002. Vertebrata (Kręgowce). In: Głowaciński (ed.). Red list of Threatened Animals in Poland. PAN, Instytut Ochrony Przyrody, Kraków, 13-22.

GŁOWACIŃSKi Z. \& RAFIŃSKI J. (eds). 2003. Atlas of the Amphibians and Reptiles of Poland. Status, Distribution, Conservation. Główny Inspektorat Ochrony Środowiska, Warszawa, $151 \mathrm{pp}$.

ICHNIOWSKA-KORPULA B. 1994. Cykl życiowy i pionowy zasięg występowania płazów (Amphibia) obszaru Łysogór Krainy Gór Świętokrzyskich. Studia Kieleckie 4, 84: 71-83.

JuSZCZYK W. 1987. Płazy i gady krajowe. Vol. 1-3. PWN, Warszawa, 240+384+213 pp. 
KowAlEwSKi L. 1985. Płazy i gady (Amphibia et Reptilia) Świętokrzyskiego Parku Narodowego. Fragm. Faun. 29 (12): 235-274.

WoJdAn D. 1997. Występowanie i ochrona populacji traszek (Triturus) w Świętokrzyskim Parku Narodowym. Rocznik Świętokrzyski. Seria B - Nauki Przyrodnicze 24: 21-29.

\section{STRESZCZENIE}

[Nowe stanowiska rzadkich gatunków plazów (Amphibia) i gadów (Reptilia) w Świętokrzyskim Parku Narodowym]

W latach 2002-2005 badano występowanie i rozmieszczenie rzadkich gatunków płazów i gadów w Świętokrzyskim Parku Narodowym. Z tego terenu odnotowano 14 gatunków płazów, z których 2 gatunki: grzebiuszkę ziemną (Pelobates fuscus) i ropuchę paskówkę (Bufo calamita) uznano za zagrożone na terenie Parku. Oba te gatunki obserwowano zarówno w środowisku lądowym jak i wodnym (osobniki dojrzałe płciowo i kijanki). Znaleziono 25 zbiorników wodnych, w których regularnie rozmnażały się płazy. Odnotowano 6 gatunków gadów, w tym gniewosza plamistego (Coronella austriaca) - gatunek bardzo rzadki. Na terenie Parku większe szanse na przetrwanie mają rzadkie gatunki płazów, natomiast mniejsze - gadów, co wynika z mniejszej liczebności ich populacji. 